\title{
Making Sense of Turkey's Air and Missile Defense Merry-go-round
}

\author{
S1tk1 Egeli \\ Izmir University of Economics
}

\begin{abstract}
At some point during 2013, Turkey's political authority began to treat the incountry development and production of long-range air and missile defense systems as a priority. Soon after, they announced their decision to favor a Chinese offer that came complete with licensed production and the promise of technology transfer. Yet, with this decision came NATO's objections and challenges around integration and information security. The 2015 decision to rollback the pro-China decision, and opt instead for the indigenous development of air and missile defense systems (in close conjunction with a foreign technological and industrial partner) was triggered by Turkey's disillusion with the content of China's technology transfer package. Subsequently, this new partner became a team comprising France and Italy; Turkish industry tied itself to this team in developing Europe's next-generation missile defense capability. Then came the Turkish government's 2017 decision to purchase off-the-shelf, standalone S-400 systems from Russia. This decision was an anomaly, and had all the characteristics of a top-down decision cycle running afoul of technical, operational, and industrial criteria. Turkey's political figures have justified the S-400 order by citing the benefits of in-country production, access to technologies, not to mention the West's refusal to sell comparable systems; but these justifications have been refuted by the Russian side and/or in discordant statements by Turkish institutions, authorities, and political figures themselves.
\end{abstract}

Keywords: Air defense, missile defense, Turkish defense policy, Turkish defense industry, NATO

\section{Prologue}

Turkey's 2013 preference to have a Chinese supplier to meet its pressing air and missile defense needs, followed by Ankara's more recent order for Russia's S-400 systems, brought about a rush of analyses and commentaries - both scholarly and otherwise. The majority dwells upon the political and strategic ramifications with respect to Turkey's defense and security ties with Russia, NATO, the U.S., and the West at large. A few sought to identify and elaborate on the technical, technological, and operational aspects, as well as the consequences of Ankara's consecutive decisions to acquire air and missile defense systems from non-Western suppliers. Systematic and scholarly attempts to scrutinize Turkey's actions within the context of a historical continuum (by paying tribute to organizational, industrial, and long-term policy objectives) are even less common. Through this article, we seek to fill this gap by analyzing, in consummate detail, Turkey's efforts and initiatives to meet

Sttk1 Egeli, Assistant Professor, Izmir University of Economics. E-mail: sitki.egeli@ieu.edu.tr. 
its air and missile defense requirements over the last three decades. We attempt to reveal the dynamics and outcomes of the complex interplay between technical, technological, operational, organizational, and defense industrial factors and considerations underlying Turkey's air and missile defense endeavor. This enables us to judge whether the disparate, seemingly contradictory, and at times perplexing decisions made in Ankara fit into a larger and predictable pattern, or whether they stand out as anomalies and improbable exceptions.

\section{Turkey's Threat Picture and Responses}

Turkey's geographic environment abounds in airborne threats. These threats involve the classical elements of air power in the form of fixed- and rotary-winged aircraft, as well as the more problematic ballistic and cruise missiles. At present, four regional states (Russia, Israel, Saudi Arabia, and Greece) possess air forces on a par with, or superior to, Turkey's. ${ }^{1}$ Eight states in the region (Russia, Armenia, Azerbaijan, Iran, Syria, Israel, Saudi Arabia, and Greece) have short, medium, and intermediate range ballistic missiles capable of reaching Turkish territory. ${ }^{2}$ Likewise, six states in Turkey's immediate vicinity (Russia, Azerbaijan, Iran, Syria, Israel, and Greece) field advanced cruise missiles. ${ }^{3}$ This is a an environment under a serious air and missile threat; the complexity of this threat is likely to increase due to recent setbacks in efforts to contain the proliferation of chemical and nuclear weapons in the region. Aircraft, especially ballistic missiles, are ideal delivery platforms for such weapons of mass destruction. ${ }^{4}$

To counter and eliminate the threat of air and missile threats, over the years Turkey has relied on its large inventory of fighter aircraft. Ground-based elements of air defense supplement this inventory. A comprehensive network of detection and tracking sensors (used to assign and direct fighter aircraft and surface-to-air weapons to their airborne targets) is a less visible, yet equally important aspect of its defense system. These sensors comprise air search radars, mostly supplied and sustained through NATO programs and funds. Not to be overlooked is the critically important command-control-communication $\left(\mathrm{C}^{3}\right)$ infrastructure, which connects friendly aircraft, ground-based defenses, and sensors with each other to constitute a fully integrated, multi-layered, and closely coordinated air defense effort. Turkey's dedicated air defense $\mathrm{C}^{3}$ infrastructure is structured in close conjunction with NATO's - through what's called ACCS (Air Command Control System). ${ }^{5}$

The additional challenges and complications caused when an adversary employs cruise and ballistic missiles warrant a special entry here: Cruise missiles fly very long distances at very low altitudes, enabling them to take advantage of the earth's topographic features to avoid detection and engagement by air defense sensors and weapons. Unless defenders use specialized tactics and hardware, cruise missiles leave them little warning time to take defensive measures. When these missiles get close to their targets, they can be intercepted by close-in defense weapons, but the size of the area and the number of targets that can be protected with such last-resort defenses is limited.

\footnotetext{
Appraisal of classical elements air power based on quantities of $4^{\text {th }}$ generation combat aircraft in the inventories of Turkey and other regional states, drawn from International Institute for Strategic Studies, The Military Balance 2014 (London: Routledge, 2014).

Sttkı Egeli, “Turkey Embarks Upon Ballistic Missiles: Why and How?," Uluslararası İlişkiler 56 (2017): 6-7.

Data on regional cruise missile inventories compiled from author's own archive.

4 Henry Sokolski, "In the Middle East, Soon Everybody Will Want the Bomb," Foreign Policy, May 21, 2018, https:// foreignpolicy.com/2018/05/21/in-the-middle-east-soon-everyone-will-want-the-bomb/.

5iles Ebbutt, "NATO ACCS Passes Major Milestone," Jane's International Defence Review, May 2013, 16.
} 
In contrast with low-flying cruise missiles, ballistic missiles can quickly climb to the upper layers of the atmosphere and into space, creating an extra challenge for defenders. This is a completely different aerodynamic sector, where they cannot be tracked or intercepted by traditional air defense sensors and weapons. Fighter aircraft and air-search radars become irrelevant when pitted against ballistic missiles. The current generation of long-range/ high-altitude surface-to-air missile (SAM) systems fares slightly better, and with some enhancements, they could be partially effective against incoming ballistic missiles in the last phase of their flight. During this terminal phase, ballistic missiles have re-entered the earth's atmosphere and they are in a steep, high velocity dive toward their targets. However, only a small area can be protected with terminal-phase defenses (i.e., the size of a city). More significantly, ballistic missiles travelling farther than 1,000 kilometers cannot engage in this terminal phase due to the excessive approach speeds. The only practical and reliable way to stop longer-range ballistic missiles is to intercept them when they are still in space, or when they are re-entering the atmosphere. Exo-atmospheric or upper-tier interceptors are necessary at this point - modern day equivalents of the Reagan-era Star Wars gadgets. Dedicated earlywarning satellites (powerful missile tracking radars positioned close to an adversary's missile launch areas), and a dedicated, fully automated $\mathrm{C}^{3}$ architecture (to run and coordinate the entire effort) need to supplement these terminal and upper-tier interceptors, creating an even larger challenge. Unfortunately, these specialized and cutting-edge technologies are so advanced and expensive that only a handful of countries possess exo-atmospheric missile defense capabilities. The U.S. leads the race by far, having spent over $\$ 1$ trillion on missile defense since the 1950s. Israel is second thanks to financial and technological backing from the U.S. ${ }^{6}$ Russia, China, and India have active programs to field comparable upper-tier interceptors, whereas France and Italy have opted to combine their strengths and create a collaborative scheme. This is where the list stops. Other states either buy missile defense systems from the U.S., or rely on Washington's protective umbrella, extended through bilateral or multilateral arrangements. The most prominent and concrete among the arrangements is NATO's EPAA (European Phased Adaptive Approach) - a U.S.-led scheme that Turkey and other European members of the Alliance have relied on for missile defense since $2011 .{ }^{7}$

\section{Turkey's Air and Missile Defense Efforts}

If we shift our focus to Turkey's air defense posture, in which fighter aircraft traditionally have been the dominant element, the Turkish military has not been without ground-based elements of air defense. ${ }^{8}$ From the mid-1950s onwards, Turkey received a relatively large number of Nike Ajax and Nike Hercules SAM batteries from the U.S. ${ }^{9}$ These were long-range air defense missiles, aimed at engaging large targets flying at medium and high altitudes. Since no replacements were forthcoming, they were kept in service well into the 2000s, though their worth in modern air combat was already nominal. Throughout those years, the only other air defense weapons to supplement the Nike Hercules batteries were the large

6 Stew Magnuson, "Hypersonic Weapons Race Gathers Speed," National Defense Magazine, last modified October 10, 2015, http://www.nationaldefensemagazine.org/archive/2015/August/Pages/HypersonicWeaponsRaceGathersSpeed.aspx.

S1tk1 Egeli, Füze tehdidi ve NATO füze kalkanı (Istanbul: Bilgi Üniversitesi, 2014): 32-7.

8 Can Kasapoğlu, "Turkey’s S-400 Dilemma" (EDAM Foreign Policy an Security Paper Series 2017/5, July 2017): 1.

For comprehensive overview of Turkey's air defense systems, see Sertaç Canalp Korkmaz and Arda Mevlütoğlu, “Turkey's Air Defense Umbrella and S-400" (ORSAM Report 213, September 2017), http://orsam.org.tr/files/Raporlar/213/213_eng.pdf, $14-15$. 
inventory of anti-aircraft artillery and low-altitude, very short-range SAMs operated by army and air force units.

The Gulf War of 1991 was a wake-up call for Turkey. Fortunately, the Iraqi Scud missiles (or the chemical warheads that those missiles might carry) did not target Turkish territory. Still, the war exposed the serious shortcomings of Turkey's modern air defense capabilities, as well as its complete lack of preparedness in the face of ballistic missile threat. Responding to Turkey's stress calls, NATO allies deployed a handful of Patriot SAM batteries to provide rudimentary capability. But controversy and divergences between NATO allies prior to this deployment raised serious doubts in the minds of Turkish military planners and the public alike. $^{10}$

Shortly after the Gulf War was over and NATO Patriots were withdrawn, Turkey initiated a scheme to acquire modern air defense systems to replace its outdated Nike Hercules batteries. Yet the fervor died out quickly, and when there was an opportunity to select U.S.-made hardware (financed through the Gulf Defense Fund) instead of Patriots missiles, the Turkish air force opted for 80 additional F-16 fighter aircraft. ${ }^{11}$ Although the Turkish military still kept its requirement for modern air and missile defense systems, funding these systems was not a high priority. Instead, in mid-2000s, the Turkish air force ordered second-hand I-Hawk SAM batteries from U.S. Army stocks. They were medium-range (40-50 kilometer) air defense systems devoid of any tangible missile defense capacity. The second-hand I-Hawks were already 30 years old, and only a 'stop-gap' solution until they could acquire modern air defense systems. All the while, the year 2003 and the U.S. invasion of Iraq witnessed yet another contentious round of NATO Patriot deployment to Turkey. ${ }^{12}$

\section{T-LORAMIDS and the Chinese Ordeal}

In 2003, only months after the AK Party government came to power, Turkey introduced a new policy in defense procurement and defense industry activities. Licensed- and joint-production were replaced by the indigenous development model, in which in-country production was extended to include local design and development of most categories of defense equipment. ${ }^{13}$ Air defense systems were among the hardware that would be developed locally. In 2006, Turkey's defense industry and procurement authority SSM (Undersecretariat for Defense Industries) ran a feasibility study; the study concluded that shorter range air defense systems could be developed by Turkey's rapidly expanding defense industry, whereas technologicallydemanding long-range air defense systems should be purchased abroad. ${ }^{14}$ Based on the study's findings, the SSM's Executive Committee, headed by Prime Minister Erdoğan, decided on three parallel air defense projects: two nationally developed low- and medium-altitude SAM systems, and one foreign-made long-range SAM solution (to be procured through industrial cooperation). Contracts for the first two projects were signed in 2009 and 2011, and they were subsequently named Hisar-A and Hisar-O. Progress on the third project, which came to be known as T-LORAMIDS (Turkey's Long-Range Air and Missile Defense System), was not nearly as smooth or conclusive.

\footnotetext{
${ }^{10}$ Serhat Güvenç and Sitkı Egeli, “NATO'nun füze savunma sistemi ve Türkiye,” Ortadoğu Analiz 40 (2014): 22.

${ }^{11}$ Güvenç and Egeli, "NATO'nun füze savunma sistemi ve Türkiye," 22.

12 Güvenç and Egeli, "NATO'nun füze savunma sistemi ve Türkiye," 22.

13 "Savunmada ortak üretim dönemi bitiyor," Hürriyet, July 7, 2015

14 “Bayar: füzede öncelik Çin'de," NTV, last modified December 6, 2013, https://www.ntv.com.tr/turkiye/bayar-fuzedeoncelik-cinde,TWJHZ1VNDEOACLqV3OBNKg.
} 
In 2009, T-LORAMIDS began with the launch of a formal tender for 12 SAM systems comprising search/engagement radars, 72 launchers, and 288 missiles - all to be manufactured and sustained with extensive involvement of Turkish industry. ${ }^{15}$ T-LORAMIDS, with a \$4-billion budget cap, demanded an air defense system that would be effective against aircraft up to 120 kilometers away. Its capability to intercept ballistic missiles was a secondary requirement. In the words of SSM Undersecretary, the category of air defense systems that T-LORAMIDS sought were “... more successful against aircraft, but it was almost impossible for current technology to provide complete protection against ballistic missiles". ${ }^{16}$

After several extensions, in 2011 Turkey received proposals from four contenders: the U.S. offered Patriot, Russia came up with Antey-2500 (S-300V), China proposed FD-2000, and the Eurosam joint-venture between France and Italy tabled $S A M P-T$. The ensuing evaluation process was painstaking. Besides the cost and performance of the offered systems, delivery schedules and the extent of Turkish industry's involvement were compared, and laboriously scored, by SSM. At the beginning of 2013, when the results were finally presented to the Executive Committee, SSM was faced with shocking news: Turkey's top political figure was not happy with off-the-shelf procurement of such a big-ticket item, nor did he find it acceptable that there was no upper-tier missile defense capability in the competition. Instead, Prime Minister Erdoğan instructed the SSM to proceed with an indigenous project aimed at the in-country development of more capable missile defense systems. ${ }^{17}$ Paradoxically, less than a month before, the SSM Undersecretary had publicly announced that Turkey chose to concentrate on developing short and medium-range air defense missiles because longerrange systems in the class of Patriot went beyond Turkey's capabilities; there was no point in pursuing the impossible. ${ }^{18}$

Why such an about-face? Besides Prime Minister Erdoğan's obvious motivation to invest this extensive capital in local industries, developments in the preceding months may have altered his thinking and priorities. One development was the June 2012 shooting of a Turkish RF-4E reconnaissance plane by Syria's air defenses off the Mediterranean shores. This incident convinced Erdoğan of the value and strategic significance of ground-based air defenses (which was retrospectively recognized by those in his inner circle). ${ }^{19}$ Likewise, Turkey's concerns over the sporadic use of ballistic missiles in Syria's civil war, and the now customary bickering over NATO's 2012 deployment of Patriot batteries to Turkey, must have reinforced Ankara's conviction..$^{20}$ Another development during this period was Ankara's diplomatic crossfire with Tehran and Moscow over Turkey's acceptance of NATO missile defense radar on its territory. In response to the Kürecik radar, Russia and Iran blatantly threatened Turkey, suggesting that their ballistic missiles would now be targeting Turkey. ${ }^{21}$ Coupling this threat with increasing concerns over Iran's rapidly advancing nuclear weapons

\footnotetext{
15 Unless cited otherwise, data on T-LORAMIDS compiled from multiple issues of Savunma \& Havacilık magazine, 20092014 period.

16 “SSM Head Bayar: Turkey’s Attack Helicopter has Good Export Prospects," Today's Zaman, September 23, 2013; "HQ-9 ve Patriot'un yetenekleri kisıtll," Hürriyet, February 17, 2014.

17 Lale Saribrahimoğlu, "Turkey Abandons USD4 Billion T-Loramids SAM System Buy," Jane's Defence Weekly, January $30,2013,5$

18 "Yerli tabanca için hareket," Hürriyet, December 14, 2012.

19 Mehmet Acet, "Sirada ne var?," Yeni Şafak, October 30, 2017.

20 "Turkey Considers Patriot Deployment," Jane's Defence Weekly, November 14, 2012, 14; "NATO Sets up Missile Defense Shield in Turkey," Deutsche Welle radio, January 20, 2013, https://www.dw.com/en/nato-sets-up-missile-defense-shield-inturkey/a-16535457.

21 “Tehran Threatens Ankara with New Missile System," Hürriyet Daily News, July 3, 2012; "Moskov'dankalkanuyarısı," Cumhuriyet, November 24, 2011.
} 
program, it is not surprising that Turkish leadership wanted to acquire full-fledged missile defense capabilities.

Faced with the Prime Minister's shift in priorities, SSM quickly adapted to the changing circumstances, and instead of cancelling the ongoing competition, it came up with a middleground formula, which combined the wishes of the political authority with the existing framework of the T-LORAMIDS competition. Accordingly, the contenders were asked to supplement their offers with a comprehensive package for technology transfer that would enable Turkish industry to develop more advanced air and missile defense systems. ${ }^{22}$ Apparently, this last-minute addition did not, however, elaborate which technologies the Turkish authorities were seeking. Some contenders complained, without effect, that technological cooperation in support of a complex indigenous development scheme constituted a different requirement and must be handled as a separate program. ${ }^{23}$

Late in the summer of 2013, SSM finished evaluating the revised proposals containing provisions for the transfer of technology, and merged these into a delicate evaluation and scoring formula. In September 2013, the findings were again presented to the Executive Committee. This time, the committee reached a decision and announced a winner: China Precision Machinery Import-Export Corporation (CPMIEC) and its offer for the FD-2000 systems. Europe's Eurosam came in second, and the U.S. Patriot offer, third. Russia's S-300V proposal was eliminated altogether due to its excessive price, nearly 2.5 times the price of the lowest bid. ${ }^{24}$ Understandably, the news of a Chinese air defense system coming out on top in a NATO country vibrated strongly around the world. Yet, for immediate observers, the outcome was hardly surprising. ${ }^{25} \mathrm{At} \$ 3.4$ billion, the Chinese offer was not only below SSM's forecasted budget, but $\$ 1$ billion less than the second lowest bid. The Chinese contender scored highest on technical and performance grounds. CPMIEC's delivery schedule, contractual terms and conditions, and financial package, as well as industrial cooperation and technology transfer offers, were superior. ${ }^{26} \mathrm{With}$ highest points on all accounts, the Chinese win was the outcome of a bottom-up decision-making process, supported and endorsed by all actors from end-user and procurement bureaucracy to political authority.

Nonetheless, as the events of the next two years would reveal, the selection process was neither flawless, nor was its end result truly actionable. The first drawback and consequent stumbling block was related to the transfer of technology. To accommodate the political authority's desire for in-country development, the requirement was added in haste to the original T-LORAMIDS framework. Apparently, SSM's description of technology transfer was vague, and the commitment from the Chinese winner was imprecise and open-ended. Two years later, when contract talks with China were about to collapse, Turkish authorities admitted that the high-level, abstract and slogan-like commitments for technological cooperation were of little value because they did not lead to an agreement during contract talks. ${ }^{27}$ Instead, they admitted that all the details, objectives, and recipient entities of technology transfer should

22 Lale Sarribrahimoğlu, "Turkey to Buy and Co-develop T-Loramids SAM," Jane’s Defence Weekly, March 27, 2013.

23 İbrahim Sünnetçi, “CPMIEC ve EuroSam'ın gözünden T-LORAMIDs," Savunma ve Havacıllk 166 (2014): 43.

24 "Başbakan Erdoğan: füze için teklif gelirse düşünürüz," Bugün, October 25, 2013.

${ }_{25}$ Burak Ege Bekdil, “Turkey May Adopt Chinese Air Defense System,” Defense News, June 24, 2013, 1.

${ }^{26}$ Interview with SSM Undersecretary in Cansu Çamlıbel, "Turkey Cannot Ignore Western Concerns over Missile Deal," Hürriyet Daily News, February 17, 2014.

${ }^{27}$ SSM Undersecretary İsmail Demir's comments in "Stratejik hava savunma sistemleri ve Türkiye'nin yol haritası," panel discussion organized by SETA, October 26, 2015, video, 2:10:38, accessed July 13, 2018, https://www.youtube.com/ watch?v=Q2A3A_3Y73Q. 
have been identified at the outset. Consequently, despite countless rounds of meetings to bridge the gaps, the parties' inability to agree on the scope and content of technology transfer prevented any progress, and led to the demise of not only the Chinese offer, but the whole T-LORAMIDS project. ${ }^{28}$

A second shortcoming of the T-LORAMIDS evaluation process concerned the SSM and its Executive Committee's failure to sufficiently consider the ramifications of selecting a nonWestern supplier for a complex defense system (which would be connected to NATO's air defense architecture) on Turkey's foreign relations and alliance ties. As Turkish authorities later admitted, the prime focus of SSM's evaluation during this first phase was limited to "such technical criteria as local content, industrialization and technical proficiency, (whereas) the ramifications and consequences with respect to international relations and the global conjuncture were not among the principal factors". ${ }^{29}$ In the words of a prominent analyst of Turkey's defense programs, "for an extremely complex technical and political problem, it turned out that the evaluation was done on purely technical grounds, without involvement of strategic, political and legal dimensions. However, these are strategic systems with direct consequences for national security, foreign relations and military relations." ${ }^{\prime 30}$

Not surprisingly, NATO strongly objected to Turkey's decision to select a Chinese supplier, and this created immediate strain on Turkey's relations with its allies. While recognizing each allied nation's right to choose their own defense equipment, NATO's Secretary General stressed, "seen from a NATO perspective, it is of utmost importance that the systems nations plan to acquire can work and operate together with similar systems in other allied nations. That's what we call interoperability." 31 The critical keyword to achieve such interoperability was integration, implying the integration of new Turkish-owned systems with NATO's existing electronic and digital architecture. In the words of NATO's Secretary General, "the Alliance had difficulty understanding how Turkey would manage to integrate an air defense system manufactured by China by using the technology of its NATO allies." ${ }^{32}$ The U.S. shared NATO's worries over interoperability and integration, and it has previously imposed sanctions on the Chinese winner of the competition for violating Washington's Iran, North Korea, Syria Nonproliferation Act. Thus, any Turkish companies who interacted with the CPMIEC risked being subjected to the same sanctions. ${ }^{33}$

On the other hand, it would be unfair and inaccurate to claim that the SSM and Turkish air force overlooked the importance of NATO interoperability. Integrating Turkey's new air and missile defense systems with Turkish, thereof NATO's air defense $\mathrm{C}^{3}$ architecture, was a paramount technical requirement from the beginning of the T-LORAMIDS competition. ${ }^{34}$ In fulfilling its air defense mission, it was critical to have NATO interoperability, because the new SAM systems were expected to become part of Turkey's multi-layered, closely coordinated air defense architecture, which was in turn intermeshed with NATO. When defending against ballistic missiles, interoperability with NATO becomes even more critical,

\footnotetext{
28 "Demir: technology transfer issue main problem in air defense system bid," Daily Sabah, July 21, 2014.

29 Demir's comments in "Stratejik hava savunma sistemleri," panel discussion by SETA.

30 Interview with Arda Mevlütoğlu in "Turkish Defense Industry has achieved much, but More Ahead," Daily Sabah, November 9, 2015.

31 "Press conference by NATO Secretary General Anders Fogh Rasmussen," North Atlantic Treaty Organization, October 23, 2013, https://www.nato.int/cps/en/natolive/opinions_104257.htm.

32 "NATO'nun yanında Çin yapımı sistem olmaz," Milliyet, October 2, 2013.

33 Burak Ege Bekdil, “Controversy Deepens over Chinese Air Defenses for Turkey,” Defense News, October 7, $2013,8$.

34 For Turkish air force perspective, see interview with General Abidin Ünal in "Türk hava sahasının 7/24 yılmaz bekçisi: MHK ve HFS Komutanlı̆̆ı,” Savunma ve Havacılık 168 (2015): 63.
} 
in fact indispensable; without satellite early-warning and dedicated radar cueing (only available through NATO), SAM systems do not have a high chance of detecting, let alone intercepting, incoming ballistic missiles. Moreover, from 2011 onward, parts of Turkey had already entered the protective umbrella of NATO's European Phased Adaptive Approach (EPAA) comprising upper-tier interceptors effective against longer-range ballistic missiles. Ankara had even agreed to host EPAA's forward-deployed missile tracking radar on its soil. ${ }^{35}$ The focus of NATO and its EPAA had been on longer-range missiles, hence on upper-tier interception. For shorter-range ballistic missiles, allied states were expected to resort to their lower-tier, terminal phase assets - the category of SAM system Turkey sought under T-LORAMIDS. Unless Turkey's lower-tier solution could talk and cooperate with NATO's upper-tier systems, which could only be achieved through NATO's dedicated $\mathrm{C}^{3}$ structure, dependable and full-fledged protection against ballistic missiles was rendered impossible.

Interoperability being so important, Turkish officials had devised what they thought was a workable technical solution. Accordingly, the new SAM systems purchased under T-LORAMIDS would not be connected directly to NATO's infrastructure. Instead, they would be integrated into Turkey's own $\mathrm{C}^{3}$ network, which in turn is already integrated with NATO's. A Turkish company would develop and deliver the necessary interface between missiles systems and Turkey's air defense network. While designating the Chinese company, SSM had already secured a commitment to get all the interface data necessary for such integration. Since Turkey would perform the entire integration work, Turkish authorities were convinced that there was no risk of China gaining access to classified NATO information and technology. ${ }^{36}$ With this assumption in mind, they tried to comfort NATO: "Our allies should trust us. Once the Chinese system has been installed, no reverse information flow." ${ }^{37}$ Yet, only months later the same Turkish officials recognized that "there were some concerns that we can accept regarding information security and interoperability. We are taking precautions." ${ }^{38}$

One of NATO's primary concerns was within the realm of software and cyber security. From an engineering point of view, it would be possible to integrate a Chinese system with NATO assets. However, NATO officials pointed out that the built-in software could be compromised by digital backdoors planted by Chinese developers' intent on gaining access to NATO data. The perception of China as a prime suspect of cyber espionage did not help. Like all air defense systems in its class, China's FD-2000 was a very sophisticated system, interwoven and run by complex software. Therefore, there would always be uncertainties with respect to security gaps, cyber access, and hacking. ${ }^{39}$ To minimize, or ideally, eliminate such risks, NATO procedures foresaw that all systems handling NATO-classified information would be subjected to NATO's advance security approval and accreditation. In the exceptional circumstances of systems originating from non-member nations, they would add an additional layer of scrutiny and NATO certification. ${ }^{40}$ These were long-established NATO procedures, and not created solely for Turkey's Chinese system. There was a presumption that Turkish officials would be well-informed of the requisites, and have dialogue with their

\footnotetext{
${ }_{35}$ Egeli, NATO füzekalkanı, 53.

${ }^{36}$ SSM Undersecretary Murad Bayar's comments in İbrahim Sünnetçi, “Eylül 2013 SSİK toplantısı kararları," Savunma ve Havacilk 157 (2013): 102.

37 Bekdil, "Controversy Deepens".

38 Çamlıbel, "Western Concerns".

39 "Korgeneral Hodges: NATO Çin yapımı füzeye izin vermez," Hürriyet, October 23, 2013.

40 “Enclosure 'F' on Infosec," Document C-M (2002) 40 on Security within NATO," June 17, 2002, accessed July 10, 2018, 
NATO counterparts during the evaluation process. Yet it appears that Turkish officials did not consult with NATO prior to their selection of a Chinese system. The outcome, as subsequently put forth by Turkish authorities, was deemed "the China accident". ${ }^{41}$ Turkish officials argued that a similar integration had been permitted for Greece's Russian-origin S-300 missiles. Yet, owing to the same NATO procedures, Greek S-300s had never been fully linked to the NATO system for operations in a dynamic coalition environment. ${ }^{42}$

Another concern was the industrial and information security aspect in the relationship between Chinese and Turkish industries and militaries. Normally, an industrial cooperation program entails extensive interaction between parties throughout the licensed production, delivery, initial system set-up, activation, on-site support, after-sale support, and future modification and upgrade phases - all of which meant Chinese nationals would be working with the equipment side-by-side their Turkish counterparts. The SSM Undersecretary could not have described the situation better: "We might be able to protect the data technically, but there will be a lot of interaction with the Chinese through this [process]. Is there a risk? Of course. They [the Chinese] are around, they're in the next room. That could be a risk." ${ }^{43}$ These were hardly comforting comments for Turkey's Western allies, and Ankara sought the allies' understanding and consent for the NATO integration process.

The limited scope of Turkey's suggested integration formula was another technical ambiguity. Turkish authorities were convinced that it would be enough to develop an interface to connect the Chinese systems to Turkey's $\mathrm{C}^{3}$ systems, because a Turkish network had already been integrated with NATO's. Yet, interoperability with NATO is not limited to the air defense command-control infrastructure. It calls for additional layers of interoperability, among them IFF (identify friend or foe) and Link-16 combined air-picture communications terminals, all of which Turkish air force had envisaged installing on Chinese systems. Each installation required unique security approval and accreditation by NATO's Office of Security - a challenge hardly voiced or addressed by Turkish authorities.

Meanwhile, it would be inaccurate to place the entire weight of NATO objections on technical grounds. However viable they may be, it is plausible that NATO employed and somewhat exaggerated these technical stumbling blocks to justify their own objections at political and even commercial levels. On the political front, the supply and successful integration of a Chinese solution in NATO's 'Holy Grail' of air and missile defense architecture risked tainting the Alliance's image of cohesion and solidarity. Using NATO's scarce economic resources to fund a potential adversary like China was a politico-financial consideration, which did not score well with NATO. Lastly, the equation had a commercial and arms trade dimension; awarding a multibillion-dollar contract to a Chinese competitor signified not only the loss of profits for European and U.S. manufacturers, but also risked creating a credible competitor who could tab on similar requirements elsewhere in the world.

In addition to the challenges presented in achieving NATO interoperability, which had gone far beyond what Turkish decision-makers had anticipated, the existing U.S. sanctions on the Chinese winner of the T-LORAMIDS competition added to the complications. It is still not clear if Turkish decision-makers knew about the sanctions prior to their selection

${ }^{41}$ SSM Undersecretary Murad Bayar comments during NATO Industry Forum, cited in Joshue Kucera, "Turkey Insists it is Solving Chinese T-Loramids Dilemma," IHS Jane's Defence Weekly, November 14, 2013.

${ }_{42}$ Kucera, "Turkey Insists".

43 Kucera, "Turkey Insists". 
of CPMIEC, but once the decision was made, they quickly dismissed them as non-binding and irrelevant. "True that the Chinese firm is in U.S. sanctions list", contended SSM Undersecretary, "but it is not a NATO or United Nations list". ${ }^{44}$ Developments would soon prove otherwise. Hardly two months had gone by when the Turkish defense industry's flagship Aselsan discovered first-hand the relevance of U.S. sanctions. When Aselsan asked the world's leading investment bank to advise and underwrite its public offering, it was faced with a blunt rejection letter, stating, "If it is possible that you will work with the Chinese company, CPMIEC, we would not work with you". ${ }^{45}$ Elsewhere, American officials were quick to remind their Turkish counterparts that dealing with a sanctioned Chinese company risked legally hampering existing and future cooperation between U.S. and Turkish defense companies ${ }^{46}$ For Turkey's fledgling defense industry, which had traditionally relied on U.S. markets for a sizable portion of its exports and purchased items, this was the harbinger of the major difficulties that lie ahead if Ankara went through with the Chinese deal. ${ }^{47}$

In November 2015, Turkish authorities announced that the T-LORAMIDS project, and together with it the selection of CPMIEC, was cancelled. In retrospect, selecting a Chinese solution was a bold step, taken without appreciating and anticipating the full range of technology transfer, foreign policy, alliance ties, and interoperability ramifications. Irrespective of the contrary official statements and media stories, the insurmountable ambiguities and shortcomings of the pro-China decision were indicative in the developments that took place first few months after the decision. Even more astonishing was the length of time it took for Turkish authorities to recognize this and reverse their decision.

\section{Ascent of Indigenous Track}

Throughout 2014 and 2015, while the Chinese winner was in contract negotiations with SSM, there were less visible developments taking place. One concerned the progress of incountry development of air and missile defense systems, and the other focused on attaining the same goal through cooperation with European partners. The two initiatives were not necessarily perceived as in competition with one another, but they certainly progressed to the detriment of the Chinese deal, and eventually helped bring about its demise.

In December 2013, ten weeks after SSM selected the Chinese company, Turkey's largest defense contractor, Aselsan, announced that they were ready to develop a long-range air defense system. Contending that outside sources would never give Turkey the sensitive technologies it needed, Aselsan officially applied to SSM for in-country development. ${ }^{48}$ No doubt Aselsan's new self-confidence was boosted by its successful test-firing of the Hisar-A, low-altitude SAM only a few months earlier. ${ }^{49}$ From then on, regardless of how ambitious and risky it might be, indigenous development became the prime track of Turkey's air and missile defense endeavor. SSM negotiated and conducted studies with local industries from 2014 to the beginning of 2018; in January 2018, SSM and Aselsan signed a hefty development contract for the Hisar-U. This was the Hisar family's long-range offspring, whose low- and

44 Sünnetçi, "2013 SSİK," 102.

45 Erdal Sağlam, "Merrill Lynch Refuses to Serve Turkish Defense Firm," Hürriyet Daily News, December 5, 2013.

46 Sağlam, "Merrill Lynch".

47 “Turkish Arms Exports up 20 Percent," Hürriyet Daily News, December 11, 2014.

48 “Aselsan uzun menzilli milli rokete talip oldu," Haberturk TV, December 13, 2013, accessed July 16, 2018, https://www. haberturk.com/tv/gundem/video/aselsan-uzun-menzilli-rokete-talip-oldu/106317; "New Options Emerge in Disputed Air Defense Deal," Hürriyet Daily News, April 8, 2014.

49 “Türkiye'nin ilk yerli füzesi atıldı,” Sözcü, October 6, 2013. 
medium-altitude derivatives were already being test-fired. The Hisar-U contract, worth circa $€ 500$-million, foresaw the delivery of one system ready for operational testing by $2021 .{ }^{50}$

Parallel to the slow but steady progress toward in-country development, a more curious dialogue between SSM and two European governments has been taking place. Despite the Chinese win, SSM had never excluded European and U.S. contenders from the T-LORAMIDS competition. They continuously asked the contenders to extend the validity of their proposals. SSM argued that if contract talks with the Chinese failed, they would invite the secondranking European, and third-ranking U.S. contenders back for consideration. What is striking under the light of future developments is that Russia and its offer for S-300V was excluded altogether, and Ankara turned down Moscow's pleas to renew its offer. ${ }^{51}$

Compared to the Americans, the French and their Italian partners were more active and determined in their efforts to roll back the outcome of T-LORAMIDS and create a new opportunity. Capitalizing on the government-to-government dialogue initiated by the French President's January 2014 visit to Ankara, the French-Italian company Eurosam held several rounds of meetings with Turkish officials and industries. ${ }^{52}$ They offered an expanded version of the technological cooperation proposal they had already made for T-LORAMIDS. Instead of the licensed-assembly of Eurosam's existing SAMP/T solution, Turkish companies were invited to take part in the joint-development and subsequent joint-production of a new generation of missile-defense-capable SAM systems alongside French and Italian industries. Representing the next iteration of their current SAMP/T, the new system would be capable of intercepting longer-range ballistic missiles (presumably in the 1,000 to 3,000-kilometer bracket). As subsequent events prove, the Eurosam offer was appealing to Turkish authorities and industries alike. ${ }^{53}$ In addition to satisfying Turkey's long-standing need to counter the threat posed by long-range ballistic missiles, it also held the promise of introducing Turkish companies to cutting-edge missile defense technologies. By taking advantage of European industries' experience and head start in this field, Turkey could expect to minimize the risks and costs associated with developing complex and advanced systems.

By mid-2014, Turkey was showing keen interest in the Eurosam offer. ${ }^{54}$ Prime Minister Erdoğan acknowledged the problems over joint-production and technology transfer within the Chinese offer, and announced that Turkey was communicating with France about jointproduction. ${ }^{55}$ The talks involved the Turkish, Italian, and French governments, as well as their respective defense companies. The negotiations were laborious and detail-oriented, slow and time-consuming. During this long process, there were gestures like Italy's 2016 deployment via NATO of a SAMP/T battery to Turkey to replace the U.S. and German Patriots that had been abruptly withdrawn. ${ }^{56}$ Finally, in July 2017, the parties announced that they had signed a framework agreement, followed by a Letter of Intent in November of the same year. In these agreements, Turkey, France, and Italy committed to jointly defining their air and missile

\footnotetext{
50 "Milli füze savunma sisteminde imzalar atıld1," C4 Defence, January 16, 2018, accessed July 16, 2018, http://c4news.me/ MZvHr.

51 "Rusya füze ihalesine dahil olmak istiyor," kokpit.aero, May 7, 2014, accessed May 8, 2014, http://kokpit.aero/fuzeihalesinde-rusya-teklifi-yeniledi.

${ }_{52}$ Burak Ege Bekdil, "French Industry Seeks a Comeback to Turkish Market," Defense News, March 10, 2014.

53 Sünnetçi, "CPMIEC gözünden" 43; "ASELSAN, EUROSAM ve ROKETSAN, hava ve füze savunma sistemi için el sıkıșt,," MSI 148 (August 2017): 10.

54 "Turkey Turns to Europe for Billion-Dollar Missile Deal," Daily Sabah, June 10, 2014.

55 “Turkey to Continue Missile System Talks with France," Daily Sabah, September 8, 2014

56 “NATO Chief Welcomes Italy's Deployment of Missile Defense in Turkey,” Daily Sabah, June 14, 2016.
} 
defense requirements for the future. Symbolically enough, they signed the document on the sidelines of a NATO Defense Ministers meeting in Brussels. ${ }^{57}$ Crowning the entire process, the French, Italian, and Turkish governments jointly awarded a contract to Eurosam and its Turkish industry partner in January 2018, allocating them with funds to proceed with the concept definition studies of Europe's new tripartite missile defense solution, intended to become operational by the mid-2020s. Eurosam presented the scheme as a 25 -year, $€ 11$-billion effort comprising the development of not only ground-based solutions, but also next-generation ship-based air and missile defenses. ${ }^{58} \mathrm{In}$ fact, the scheme opened the door to another outstanding Turkish requirement, envisaging in-country construction of $T F-2000$ air defense frigates. In stark contrast with Turkey's geostrategic circumstances, TF-2000 requirements did not call for ballistic missile shooter capability, and confined the vessels' mission to assisting NATO's missile defense effort with onboard radar and data link. ${ }^{59}$ Following the cooperative scheme with Europe, the new missiles may as well have been designated for the TF-2000 frigates. This would bring the benefit of adding missile defense capability to TF-2000, therefore diversifying Turkey's missile defense options.

What is important here is that the cooperative scheme with Europe is not seen and treated as being in contradiction or competition with Turkey's own efforts to develop indigenous systems. In the eyes of Turkish authorities, “cooperation [with Europe] is part of Turkey's own air and missile defense effort, [as it has been structured] in a manner to assist SSM's local development model" ${ }^{60}$ This translates into a situation in which the Hisar-U contract is envisaged by SSM as an instrument to augment Turkish industries' capabilities in the joint program, allowing the opportunity to maximize the weight, contribution, and gains of Turkish industries.

\section{S-400 Bombshell}

In retrospect, the period following the November 2015 cancelation of the T-LORAMIDS project was interesting. Local industries pressed ahead with preparations for in-country development, becoming the first and foremost route for Turkey to acquire long-range air and missile defense capabilities. In parallel, international cooperation created a shortcut to advanced technologies and capabilities required by upper-tier missile defense had come to constitute the second viable route. Then, what could be treated as a third route, there were sporadic reports of Turkey's interest in acquiring stopgap, off-the-shelf long-range air defense systems which would meet urgent operational requirements, and fill the void left by the cancellation of T-LORAMIDS. ${ }^{61}$ Most likely, SSM contacted foreign manufacturers and received their price-and-availability inputs. However, there were no signs of resolute followup activity.

57 "ASELSAN el sıkıșt1," 10; “Turkey, France and Italy to Strengthen Cooperation on Missile Defense: Sources," Reuters, November 8, 2017, accessed November 10, 2017, https:/www.reuters.com/article/us-turkey-defence/turkey-france-and-italy-tostrengthen-cooperation-on-missile-defense-sources-idUSKBN1D829I.

58 “Turkey Awards Missile System Study to Franco-Italian Group, Turkish firms," Reuters, January 5, 2018, accessed January 10, 2018, https://www.reuters.com/article/france-turkey-defence-eurosam/turkey-awards-missile-system-study-to-francoitalian-group-turkish-firms-idUSL8N1P02NS.

59 “TF-2000 HSH firkateyni,” Turkish Navy official website, accessed February 15, 2015, http://www.dzkk.tsk.tr/denizweb/ turkce/modernizasyon/firkateyn_projeleri.php.

60 “ASELSAN el sıkışt1," 10; "Uzun menzilli bölge hava ve füze savunma sistemi (umbhfss) basın bülteni," SSM press release, June 4, 2018, accessed June 14, 2018http://www.ssm.gov.tr/WebSite/contentList.aspx?PageID=1178\&LangID=1.

${ }^{61}$ Burak Ege Bekdil, "Turkey Mulls Stopgap Air Defense Acquisition,” Defense News, November 15, 2015. 
Meanwhile, throughout 2015 and 2016, there were tectonic shifts in Turkey's domestic and political circumstances. Particularly in Syria, Iraq, and elsewhere in the Middle East, Turkey's objectives and interests were rapidly becoming divergent, even contradictory with those of its Western allies, and especially with the U.S. In this sense, Washington had lost confidence in Turkey as a proficient and dependable ally under AK Party rule. Turkey's steady drift toward authoritarianism made matters worse. Negative perceptions and mistrust were reciprocal. Turkish leadership was extremely disturbed and suspicious of Washington's choice to have armed Kurdish groups as its principal ally in Syria. One outcome was Turkey's eventual rapprochement with Russia, whose relations with Ankara had recently hit an all-time low (due to Turkey shooting down a Russian aircraft along the Syria-Turkey frontier). By mid-2016, while Turkey was inching toward amending its ties with Russia, a bombshell in the form of a botched coup d'état was dropped in Ankara. It was a truly traumatic event that deeply impacted Turkey's entire range of domestic and foreign policy dealings and equations.

From the perspective of Turkey's long-standing requirement for air and missile defense systems, the impact was immediate and dramatic. Only three weeks after the coup attempt, President Erdoğan paid an official visit to Moscow; during the visit his Russian counterpart expressed that Moscow wanted to supply Turkey with the $S-400$ - the more advanced offspring of the S-300 (eliminated from T-LORAMIDS due to its prohibitive price). Ankara was receptive: Turkey's foreign minister stated, "we are forced to cooperate with other partners in buying and selling weapon systems, because there are NATO allies who refuse to sell us air defense systems or share (technology) with us". ${ }^{62}$ By October of the same year, Turkey asked that Russia submit a formal proposal for the S- $400 .{ }^{63}$ In February 2017, Turkey's Defense Minister announced that they would buy the S-400. ${ }^{64}$ The following month, he revealed Turkey's decision to use the S-400s as a standalone weapon, and not seek integration with NATO. He went on to stress that while Turkey sought the same from its NATO allies, it did not see acceptable levels of clarity and solidarity in favorable pricing and technology sharing. ${ }^{65}$ In May 2017, he announced that talks on technical aspects were finalized, and the order would be placed once financial issues were sorted. ${ }^{66}$ These financial issues held up the process longer than the technical ones. The contract, which was signed toward the end October, took effect before the end of $2017 .{ }^{67}$ The order was for one battery (plus one optional battery), due for delivery during the first quarter of 2020 (subsequently moved to July 2019). In the words of President Erdoğan, with production of the first units already underway, S-400 was a "done deal". ${ }^{68}$

Once more, Turkey was at the crosshair of its Western allies' harsh criticism. A top NATO official warned, "The same way that nations are sovereign in making their [defense

62 "Y1llardır krize neden olan dev projeyi Ruslar istiyor!," Milliyet, August 16, 2016.

63 "Turkey awaits Russia's Offer in Missile System Procurement Process," Daily Sabah, November 7, 2016.

64 “Bakan Fikri Işsk'tan S-400 açıklaması," CNNTurk, February 22, 2017, accessed February 23, 2017, http://www.cnnturk. com/turkiye/bakanfikriisiktans400aciklamasi.

65 “Bakan Işık'tan S-400 açıklaması: NATO sistemine entegre etmiyoruz," Diriliş Postası, March 16, 2017, accessed July $\quad 18$, 2018,https://www.dirilispostasi.com/turkiye/bakan-isiktan-s-400-aciklamasi-nato-sistemine-entegre-etmiyoruz$5 \mathrm{a} 7854 \mathrm{a} 818 \mathrm{e} 540432 \mathrm{e} 750718()$.

${ }^{66}$ Interview with Defense Minister Fikri Işı in TRT Haber, cited in Hakan Kılıç, "Füze tartışmasına Milli Savunma Bakanı son noktayı koydu," kokpit.aero, July 5, 2017, accessed July 8, 2017, http://www.kokpit.aero/fuze-tartismasi-bakan-isik?writer=23.

67 "Rostec CEO Reveals Bulk of Russia's S-400 Deal with Turkey,” TASS News Agency, November 2, 2017,http://tass.com/ defense/973803; "S-400 sistem tedariki basın açıklaması," SSM Press Release, December 29, 2017.

68 "S-400 füzelerinin teslimat tarihi belli oldu," t24, April 4, 2018, accessed April 5, 2018, http://t24.com.tr/haber/s-400fuzelerinin-teslimat-tarihi-belli-oldu,597115. 
acquisition] decisions, they are also sovereign in facing the consequences of that decision". ${ }^{69}$ Washington's sanctions on the Russian manufacturer of S-400 further complicated things, as Turkish parties risked having the same sanctions extended toward them. ${ }^{70}$ Ankara had gone through the same cycle less than three years ago over its pro-China decision; this new round of tensions and difficulties could not have been unexpected. What had changed? What made Turkish decision-makers opt for a trail they knew would be full of tensions and obstructions?

First and foremost was the deep trauma left by the botched coup, and the consequent shift in Ankara's threat perceptions. The survival of Turkey's regime and its top leader was now at stake, and Turkey could not count on traditional allies anymore. They were deemed to be supportive and complicit, if not directly behind the coup d'état. ${ }^{71}$ The turn of events during the coup had shown that the main danger to Turkey's rulers came from the air, and exposed the need to immediately resurrect effective air defenses over critical targets (e.g. presidential palace and parliament). ${ }^{72}$ Turkey's traditional western allies could not be trusted, because the need may well rise for protection against their weapons. Turkey's indigenous, but very short-range, solutions were hastily deployed. Conveniently enough, Russia, who had helped the Turkish government during the botched coup, was gracious enough to offer the world's most capable long-range air defense system. From this perspective, if the purchase of S-400s risked straining relations with NATO and the U.S., then that was a price Turkish leadership was ready to pay. For Turkish decision-makers, the S-400 deal carried the additional benefit of mending ties with Russia, and winning its cooperation in the Syrian quagmire. Moreover, by cozying up with Russia, Ankara was sending a message to its NATO allies that they had other options. The deal was also beneficial for Moscow: in addition to monetary gains, the S-400 offer was a skillful maneuver that would drive a wedge between Turkey and its NATO allies.

\section{Fallacy of Three Justifications}

Underlying strategic-level considerations aside, Turkish authorities justified the decision to the public with three elements: first, the S-400's favorable price; second, NATO allies' failure to meet Turkey's quest for technology transfer and joint-production; and third, the U.S. and Europe's refusal to sell Turkey air defense systems in the first place. ${ }^{73}$

The contention on favorable price is impossible to verify or refute with a high degree of certainty, because from the onset, the S-400 deal was littered with insufficient or inconsistent information. The Turkish and Russian parties' differing and interchangeable use of terms (e.g., system, battery, and battalion) further complicated the picture. In the final analysis, the Russians announced a price of circa $\$ 2.5$ billion for four batteries. ${ }^{74}$ The Turkish defense minister did not provide a price figure, but confirmed the quantities: two systems, each comprising two batteries, for a total of four batteries. ${ }^{75}$ The SSM press release issued

69 “NATO Official: Turkey Faces ‘Consequences’ If Purchase of S-400 Completed,” Defense News, October 25, 2017.

70 Barçın Yinanç, “Turkey could Face US Sanctions for S-400 Purchase," Hürriyet Daily News, February 1, 2018.

71 Adam Withnall, "Erdogan Blames Foreign Powers for Coup and Says West is Supporting Terrorism," The Independent, August 2, 2016.

72 “Külliye ve Meclis'e füze kalkanı,” Milliyet, July 28, 2016; “Artık onlar koruyacak,” Hürriyet, July 27, 2016.

73 “Erdoğan'dan S-400 yorumu: NATO'da bu imkanları yakalayamıyorsak, başımızın çaresine bakarız,” Sputnik, March 12, 2017, accessed March 15, 2017, http://sptnkne.ws/dMgN; Defense Minister in TRT Haber interview, cited in Kılıç, "Son nokta".

74 "Rusya: Türkiye, 4 adet S-400 bataryasını 2.5 milyar dolara satın aldı," Sputnik, December 27, 2017, accessed December 29, 2017, https://tr.sputniknews.com/savunma/201712271031570715-rusya-rosteh-turkiye-s400-batarya/.

75 "S-400 sistemi için S-400 füze savunma alay komutanlığ kurulacak," Habertürk, January 4, 2018; SSM, "S-400 sistem 
soon afterward clarified that the firm order was for one system (comprising two batteries), whereas the second system was optional. Turkish sources have never identified the exact makeup and quantities of the system elements at stake, but it may be possible to guess judging from Russian deployment practices. Accordingly, Turkey's firm order for one system (battalion) would normally comprise two batteries of nine quadruple launchers each, for a total of 18 launchers and 72 ready-to-fire missiles. When the second optional system (and its two batteries) is added up, the total would become 36 launchers and 144 missiles. If the \$500-million price tag cited in Russian sources for each S-400 battery is to be trusted, then the price figure for four batteries (and their 36 launchers) comes out at $\$ 2$ billion - close enough to the $\$ 2.5$-billion value announced by Russian authorities. ${ }^{76}$ Back in 2013 , the price quotes for 72 launchers (and 288 missiles) stood at $\$ 3.4$ billion for China, $\$ 4.4$ billion for Eurosam, and $\$ 8.8$ billion for Russia's S-300V. Now, Russia supplied half the quantity of launchers and missiles in return for $\$ 2.5$ billion - a discount of sorts, but nowhere close to Chinese or European price quotes during T-LORAMIDS, and this despite the fact that the S-400 contract did not include any T-LORAMIDS cost-drivers like local content, in-country final assembly, and offset trade.

Regarding Turkish officials' contention that S-400 was preferable due to Russia's acceptance of joint-production and technology transfer, is a lot easier and straightforward to reach a fair judgment: no such provision is part of the S-400 contract. Observations to this effect belong to the realm of ignorance, disinformation, or 'alternative facts'. On this, the Russian side has been very open and consistent throughout: "the consensus has been on off-the-shelf transfer; sharing of technologies has never been at stake" declared Putin's top military advisor. ${ }^{77}$ Other defense officials stressed that the S-400's internal control (source) codes would never be shared with Turkey. ${ }^{78}$ Referring to Turkish demands for localization, the S-400's Russian manufacturer touched the bounds of arrogance: "without the necessary infrastructure, it is impossible to manufacture anything. You need training, training in high technologies. The Turks understand this, too. We can provide them with all the documentation, but this would not generate any results. ${ }^{379}$ Interestingly enough, Turkish authorities close to the subject have been playing to the same tune. For instance, the Turkish Defense Minister has been clear in his statements that the S-400 was an off-the-shelf deal to meet urgent needs, and that technological know-how was a matter to be discussed if Turkey decided to exercise an optional clause of the contract at a later stage. ${ }^{80}$ Months later, President Erdoğan confirmed that joint-production applied to the second and third phases of the program; he had proposed joint development of the S-500. ${ }^{81}$ Owing to their experience with Chinese talks, Turkish procurement officials must have been well aware of the limited value of abstract and inarticulate reference to technological cooperation. Pointedly enough, in an official press release on the occasion of the S-400 contract, the SSM underlined the importance of ongoing

76 Yekaterina Chulkovskaya, "Is Russia’s Planned Missile Sale to Turkey the Real Deal?," Al-Monitor, May 10, 2017, accessed May 15, 2017, https://www.al-monitor.com/pulse/originals/2017/05/russiaplanmissilesaleturkeymilitary.html.

77 “Putin'in askeri danışmanı: S-400'leri vereceğiz, teknolojisini değil," Cumhuriyet, September 29, 2017.

78 "S-400 Dispute Highlights Ongoing Difficulties in Turkey's Rapprochement with Russia," Eurasia Daily Monitor, November 6, 2017, accessed November 10, 2017, https://jamestown.org/program/s-400-dispute-highlights-ongoing-difficultiesturkeys-rapprochement-russia/.

79 "Rusya duyurdu...S-400 sevkiyatı henüz netlik kazanmad1," Hürriyet, December 7, 2017. 28,2017

${ }^{0}$ Kilıç, "Son nokta"; "It's a done deal: Turkey plans to deploy Russian air-defense system in 2019," Defense News, November

8124 TV (@yirmidorttv), “Cumhurbaşkanı Erdoğan: Putin’e S-550 füzesini birlikte yapmayı teklif ettim,” Twitter, June 13, 2018, 11:47p.m., https://twitter.com/yirmidorttv/status/1007001580229390336. 
activities with "other countries and companies" to support Turkey's local development program - a clear reference to the Turkish industry's technological cooperation with their French and Italian counterparts. ${ }^{82}$ Paradoxically, Turkish authorities at all levels continue citing technology transfer and joint-production as the main reasons for Turkey's choice of S-400s, whereas no such technological or industrial content is to be found in the current iteration of the S-400 contract. ${ }^{83}$

Lastly, regarding the frequent contention by several high-ranking Turkish officials that NATO allies declined to sell Turkey air defense systems, there appears to be a similarly puzzling picture. ${ }^{84}$ Complaints about NATO allies', and especially Washington's double standards and lack of responsiveness in handling Ankara's demands for defense hardware, are fair and well founded. Even U.S. officials acknowledge that overly strict American export controls pushed Turkey into the arms of Russia. ${ }^{85}$ On the other hand, though, the following commentary by Turkey's presidential spokesperson reveals a double standard on Ankara's part, too:

...we long made negotiations on Patriots, [...] but we couldn't get a result, [because] the most important criterion for us is joint production, that is to say making a deal which will provide technology transfer. Unfortunately, we have not managed the reach an agreement to produce Patriots. But, Russia took a quick step in terms of joint production and thus S-400 has been implemented. Turkey does not have any concerns on buying Patriots, provided that the same conditions are set, namely joint production. So, the ball is on the U.S. court now. ${ }^{86}$

There are a number of sticking points in this line of contention. First, if Turkey's most important criterion has been joint-production, then Russia and its S-400 are exempt. Then, it is not possible to talk about a level playing field between Russia and NATO members because the latter are asked to fulfill a daunting criterion which does not apply to Russia: Russia was allowed to supply its S-400 off-the-shelf, but Turkey's NATO allies are expected to meet strict technology transfer and localization preconditions. Have Turkey's NATO allies ever been asked to supply their systems off-the-shelf under the same conditions that apply to Russia? If so, was their response negative? Unfortunately, we do not have sufficient public-domain information to provide an answer. Yet, the following comments from Turkey's defense minister may indicate that there have always been additional demands in the talks with Western suppliers: 'U.S. and European countries' attitude was not receptive. Their proposals were not competitive and did not include the sharing of technology, meaning I would sell this system, you would get and set it up as is. You can't even touch a single bolt. We cannot accept such understanding. This made S-400 talks imperative for Turkey". ${ }^{87}$ In retrospect, whereas the obstructions by the Congress may indeed prevent the supply of Patriots to Turkey, ${ }^{88}$ it appears highly implausible that France and Italy - having already

\footnotetext{
82 "Uzun menzilli hava savunma sistemi çalışmaları sürüyor," SSM Press Release, June 4, 2018, accessed July 24, 2018, https://www.ssb.gov.tr/WebSite/contentList.aspx?PageID=1178\&LangID=1.

83 "Statement by Presidential Spokesperson Ambassador İbrahim Kalın," April 5, 2018, accessed April 7, 2018, https://www. tccb.gov.tr/en/spokesperson/1696/92051/statement-by-presidential-spokesperson-ambassador-ibrahim-kalin.html.

84 "Turkey Defiant on Purchase of Russian S-400 Anti-Missile Weapon," Defense News, July 11, 2018.

${ }^{85}$ Ellen Mitchell, "Air Force Secretary Advocate Export Control Fixes Amid Controversy over Turkey," The Hill, May 29, 2018.

86 "Statement by Presidential Spokesperson".

87 Kokpit.aero, "Füze tartışması".

88 Interview with MFA Mevlüt Çavuşoğlu, Republic of Turkey Ministry of Foreign Affairs, "Dışişleri Bakanı Sayın Mevlüt Çavuşoğlu'nun Zeit Online'da Yayımlanan Mülakatı,” interview by Michael Thumann, Zeit Online, March 9, 2018, accessed March 12, 2018, http://www.mfa.gov.tr/disisleri-bakani-sayin-mevlut-cavusoglu_nun-zeit-online_da-yayimlanan-mulakati_-9-mart- 
accepted Turkey's participation in the joint-development of their next-generation air and missile defense system - would have second-thoughts on selling their current-generation $\mathrm{SAMP} / \mathrm{T}$ systems to Turkey.

No doubt all three justifications of the S-400 order are tangled in varying degrees of inconsistency and misrepresentation. In stark contrast with the September 2013 pro-Chinese decision, the outcome of a bottom-up process, the S-400 order is a good example of topdown process: the decision made first, through political deliberations, and justifications generated afterward. Rapidly-changing political circumstances in and around Turkey, and the corresponding shift in leadership's threat perceptions, must have weighed in heavily to produce such an outcome. Of course, such a high-level political decision had its own procession, rationale, and justification. Therefore, instead of questioning its wisdom, we shall focus our analysis on scrutinizing the industrial, operational, and military ramifications of the ruling.

\section{S-400's Operational Appraisal}

In the industrial and technological dimension, the decision to favor the off-the-shelf procurement of S-400s is not in line with Turkey's much-cherished goal of attaining indigenous air and missile defense capabilities. In its current shape, the S-400acquisition does not bring direct benefits to Turkey's defense industries, nor does it provide a solution, which would be interoperable, and therefore complementary to Turkey's future air and missile defense setup. This setup is being developed locally in close conjunction with Western, and more specifically, European technologies and standards. It would be unfair to discount the likelihood of prospective cooperation with Russian industry in this domain. Alternately, Turkey's first-hand experience with T-LORAMIDS suggests the insurmountable challenges in defining and operationalizing technological cooperation on an ex post facto basis, i.e., after the contract is signed and payments are made. Even if it could overcome these difficulties, successful technological cooperation with Russia would constitute a parallel, in fact competitive, effort to Turkey's current priority of developing its own air and missile defense solutions, run in close conjunction with European industrial partners.

With respect to the S-400's ability to satisfy Turkey's operational needs, thereby contributing to the overall defensive posture of the country, we first focus on the air defense dimension. Turkish authorities have already announced that S-400s would be used standalone, with no digital exchange of threat and targeting information, nor any coordination or cooperation with other assets of Turkey's existing air defense architecture. S-400is a longrange air defense system, with performance characteristics unmatched by any rivals. Its search radar is capable of detecting airborne targets up to a range of 600 kilometers, and the system can shoot down targets up to a range of 150 kilometers ${ }^{89}$ With improved, mission-specific missiles, the effective range could be extended to 250, even 400 kilometers. Yet, propaganda notwithstanding, the S-400 is bound by the same laws of physics which impose restrictions on all long-range air defense systems. Due to earth's curvature, after roughly 40 kilometers downrange, S-400 radars cannot see targets flying at low- and medium-altitudes. The more rugged the topography, the higher becomes the altitude below which S-400 radar is blinded. This is not good news for countries like Turkey, who have mountain chains and rough terrain.

\footnotetext{
89 S-400 technical information drawn from Korkmaz and Mevlütoğlu, "Air Defense Umbrella," $18-9$.
} 
When Russia deployed its S-400 to Syria, this provided vivid examples: U.S. cruise missiles flying through depressions between mountains were not detected by the Russian S-400 battery, deployed less than 50 kilometers away. Russia's fix was to immediately deploy two airborne early-warning (radar) planes to Syria, and link up its S-400 battery to high-mountain radars and batteries, so as to reduce gaps in radar coverage - all illustrating the imperative to operate as part of multi-layered, fully-integrated air defense architecture. ${ }^{90}$ When used in standalone mode, the performance and effectiveness of even the most advanced air defense system is reduced to the level of medium-range air defense systems - such indigenous examples would soon be joining Turkey's inventory through the Hisar-O project. Even worse, faced with complex and multidimensional threat scenarios involving cruise missiles, extendedrange precision-guided munitions, and low-flying aircraft, a standalone S-400 battery's own survival would be in jeopardy. This is a flaw Russian planners must already realize, for they have been attempting to sell Turkey point-defense systems to protect the S-400 batteries. ${ }^{91}$ Not surprisingly, this standalone employment does not align with Turkey's expectations for its new air defense systems - a point underlined earlier by the Turkish air force: "Fielding a single type of air defense system does not solve the problem. What is needed is layered air defense (combining different types of air defense systems). The assignment of different target types to different air defense systems must be done centrally, using an integrated commandcontrol system and its dedicated software." ${ }^{, 92}$ This is a far cry from what standalone S-400s would be delivering to Turkey.

In the realm of ballistic missile defense and how S-400s contribute to it, the prospects are even dimmer. There is little doubt that S-400 has a robust missile defense capability built around its dedicated 9M96E missiles, which are believed to be capable of terminal phase interception of incoming ballistic missiles at an altitude of 27 kilometers. This is roughly equal to Patriot's PAC-3variant and its ERINT missiles, implying that they could intercept ballistic missiles with ranges of up to 1,000 to 1,300 kilometers. It is quite possible that 9M96E missiles are included in Turkey's S-400 order. Yet, the more advanced 40N6E missiles, reputed to have an exo-atmospheric intercept altitude of 185 kilometers, have been in customization tests since $2008 .^{93}$ Even when they finally reach operational status with the Russian military, they may never be supplied to export customers, at least not in the foreseeable future. Consequently, the missile defense potential of Turkish S-400s is confined to the terminal phase. Besides, devoid of satellite early warning and cueing from dedicated missile tracking radars (such as the one at Kürecik), it is doubtful that S-400 batteries would have enough reaction time or precision to detect and engage incoming missiles with their own radar. Even overlooking such uncertainties, as the top Turkish air force authority in charge of air and missile defense once described, "Long-range air defense systems become point defense systems when pitted against ballistic missiles. The restraint is not only the shortness of their intercept distance; it also concerns the fact that longer-range ballistic

\footnotetext{
90 Tom Cooper, "Russia's Air Defense in Syria Have Some Big Problems," War Is Boring, October 6, 2017, accessed July 24, 2018, https://warisboring.com/russias-air-defenses-in-syria-have-some-big-problems/.

${ }_{91}$ "Rusya: Türkiye'ye Pantsir hava savunma sistemleri gönderemeye hazırı," Sputnik, April 25, 2018, accessed April 30, 2018, https://tr.sputniknews.com/savunma/201804251033173104-rusya-turkiye-pantsir-hava-savunma-sistemi/.

92 Demir's comments in "Stratejik hava savunma sistemleri," panel discussion by SETA.

93 "S-400 in Syria: Russia Gives Stark Warning to Turkey," Sputnik International, November 26, 2015, accessed November 27, 2015, https://sputniknews.com/military/20151126/1030773123/s400-air-defense-russia-syria-su24.html; "Russian S-300 Missile Systems Capable of Targeting Near Space Enter Service,” RT, March 12, 2015, accessed March 20, 2015, https://www. rt.com/news/239961-near-space-missile-defense/; "Rusya, S-400 için uzun menzilli füze denemelerini tamamladı," kokpit.aero, July 4, 2018, accessed July 10, 2018, http://www.kokpit.aero/s400-uzun-menzilli-fuze-deneme.
} 
missiles cannot be intercepted at all. This makes upper-tier missile defenses compulsory. And lower-tier missile defense assets must be integrated with upper-tier. This is a dimension to keep in mind while shaping Turkey's missile defense architecture." 94 This is yet another feat that the standalone S-400s cannot not hope to meet.

As a sub-category air defense mission, we should also reference the S-400's $A 2 / A D$ role (deploying long-range weapons to prevent opponents from entering a certain theater, and depriving them freedom of action in this theater). Russia's deployment of S-400s in western Syria to create a no-fly zone provides a good example. Ankara could not have failed to notice the S-400's success in restricting Turkish and American aircraft inside Syrian airspace. It is no secret that Turkish leadership had similar ambitions to set up no-fly zones over Syria, or depending on circumstances, over other conflict zones as well. ${ }^{95}$ What is frequently overlooked is that employing S-400s in standalone mode would diminish their worth for A2/ $\mathrm{AD}$ as well as no-fly zone contingencies. A standalone S-400 could not hope to positively identify friendly aircraft. This points to a situation in which deploying S-400s in a certain theater would deprive not only the opponents, but also the Turkish air force, of freedom of action, simply because there is no way to ensure that friendly aircraft are not inadvertently targeted by S-400. Besides A2/AD scenarios, this is a serious shortcoming with detrimental impact on routine air defense deployments, as well as on operations inside Turkish airspace.

The impact goes beyond national contingencies to affect joint NATO operations even more severely. "[S-400's] mere presence creates technical challenges for allied assets deployed onto the territory of that country," reminded a top NATO official. ${ }^{96}$ In daily parlance, this means that NATO allies will not be willing to take the risk of having their aircraft accidentally or inadvertently targeted; consequently, they will not allow their aircraft to operate where Turkish S-400s are present. The end result is a significant loophole in NATO's collective defense guarantees toward Turkey. In this sense, NATO allies' concerns and objections go beyond the safety of their aircraft flying in Turkish airspace, and extend into the realm of electronic and information security. A top NATO official explained the point with extraordinary detail and precision:

[S-400] system itself is less an issue as the database that will have to be built to make it operational. The value of the system is in the database [which] will be collected on the territory of a NATO ally, with all allied assets present in Turkey being mapped and logged into Russian systems. Russian personnel will be on the ground to instruct the Turkish military how to operate the complicated radars and fire control systems, handing Moscow critical intelligence on what NATO assets are in the country, where they are, and what kind of capabilities they may have. Just as it would be hard to imagine that NATO experts would be sitting in Russia for several months and feeding the database, it is hard to imagine that Russian experts will be sitting in a NATO ally and feeding a Russian system with NATO data. $^{97}$

Turkish authorities did not deny the possible involvement of Russian civilian and military specialists, and said Turkey was trying to ease NATO's concerns by entrusting S-400 setup

\footnotetext{
94 Ünal, "7/24," 63.

${ }_{95}$ Samuel Hickey, “Turkey's New Missiles," Foreign Affairs, October 20, 2017, accessed July 22, 2018, https://www. foreignaffairs.com/articles/turkey/2017-10-20/turkeys-new-missiles.

96 Aaron Mehta, "NATO Official: Turkey Faces Consequences If Purchase of S-400 Completed," Defense News, October 25, 2017.

97 Paul Mclearly, "Top NATO General (A Czech) To Europe: Grow Up," Breaking Defense, March 7, 2018, https:// breakingdefense.com/2018/03/top-nato-general-a-czech-to-europe-grow-up/, accessed July 4, 2018.
} 
and activation tasks with Turkish personnel trained in Russia - assuring no Russian presence in Turkey. ${ }^{98}$ Whether NATO allies would be satisfied with these arrangement remains to be seen. All the while, the S-400 impasse takes its toll on various dimensions of Turkey's relations with NATO allies. At the forefront is the F-35 program, through which Turkey hoped to acquire its next-generation fighter aircraft. By citing Turkey's S-400 order, the U.S. Congress took steps to suspend deliveries and, ultimately, exclude Turkey from the program. This amounts to no less than an arms embargo, damaging defense relations beyond repair. There is a widespread expectation that Turkey could be subjected to U.S. sanctions, because its S-400 order will be assessed under the Countering America's Adversaries Through Sanctions Act (CAATSA), which is already applied to Russia. ${ }^{99}$ TheS-400 is not the root cause of Turkey's rift with the U.S; a lot of the blame goes to the U.S. in the complex interplay of misperceptions and miscalculations. ${ }^{100}$ Irrespectively, the S-400 has come to represent a highly visible example of defiant behavior; it holds the potential to trigger wider restrictions on defense material and technology transactions. Despite major strides in defense production in recent years, Turkey relies heavily on its NATO allies for most defense equipment, and its fledgling defense industry remains deeply enmeshed in its Western counterparts. If the flow of spares and components is interrupted, or offset trade contracts suspended, Turkey's defense industry and military are poised to suffer significantly. ${ }^{101}$ However unfair and unjustified such restrictions may be, their outcome is an important variable to factor in the S-400 cost-benefit tally.

Leaving the NATO dimension behind, our analysis will not be complete without identifying yet another national-level consideration: electronic security and dependability. S-400 is a very complex system comprising several types and layers of electronic hardware and software. Since the system will be arriving in an off-the-shelf, 'as is' configuration, and since software codes are not part of the deal, there would be no way to guarantee that the S-400s will not be compromised electronically. An intrusion would always be possible through more conventional means of electronic warfare, as well as the more fashionable methods of cyber attack. Presumably, its Russian manufacturers would know the system's vulnerabilities better than anyone else; Russia would find itself in the best position to intrude or obstruct S-400 operations. The range of geopolitical contingencies likely to necessitate Turkey's use of S-400s all include Russia, either as a stakeholder, opponent, or potential spoiler. All of Turkey's regional adversaries are already in cordial terms with Russia. Under such circumstances, would the S-400 work as advertised? This is a question which may never be answered with a high degree of confidence. There is little value to claims that the S- 400 would be more or less as dependable and reliable as its counterparts.

\section{Conclusion and the Way Forward}

Our analysis reveals three concurrent courses for Turkey to meet its air and missile defense requirements. The first and foremost is developing such systems indigenously - a noble,

\footnotetext{
98 “Russian Experts may be Employed to Service Turkey's S-400s - Turkish Top Diplomat," TASS, last updated December 14, 2017, http://tass.com/defense/981091; Emanuel Scmia, “Turkey's Controversial S-400 Missile Transfer is Done Deal," Asia Times, June 30, 2018.

99 Serkan Demirtaş, "S-400s Becoming A More Difficult Issue for Turkey-NATO Ties," Hürriyet Daily News, March 14, 2018.

${ }^{100}$ Sitk1 Egeli, "Fighter Jet that could Break US-Turkey Defense Relations," Middle East Institute, June 26, 2018, http://www. mei.edu/content/article/fighter-jet-could-break-us-turkey-defense-relations.

${ }^{101}$ Selim C. Sazak and Çağlar Kurç, "Turkey's Slow-Cooking Crisis With Its Allies Is Coming to a Boil," Defense One, June 22, 2018, accessed June 25, 2018, https://www.defenseone.com/ideas/2018/06/turkey-crisis-allies/149203/.
} 
well-founded cause given Turkey's geopolitical circumstances. The second course, in close coordination with the first one, aims at a technological and industrial collaboration with European NATO allies to promote upper-tier missile defense capability - something that goes beyond Turkey's current technological and financial confines. Contracts for both courses were signed at the beginning of 2018, and work is already underway.

The third course concerns the off-the-shelf procurement of stopgap systems to meet urgent operational needs, because the other courses take a long time to materialize. In 2013, the prospect of using a Chinese system to meet urgent requirements collapsed for two reasons: the failure to find a workable solution for NATO interoperability, and an ill-devised focus on technology transfer. In 2017, Turkey tried again, but with Russia. The decision reflected Turkey's extraordinary political circumstances and the corresponding shift in threat perceptions. As a shortcut to immediate deployment, the S-400 deal attempted to circumvent restraints imposed by NATO interoperability, and perhaps the delivery schedule and pricing as well. But in doing so, it did not meld well with Turkey's other two, prioritized courses. Nor did it match well with Turkey's operational requirements. Consequently, the S-400 deal will find itself under constant strain and questioning.

In retrospect, Turkey cannot and should not be spending three or four times over to meet the same requirement. First and second courses for in-country and collaborative development are already underway, and they can be expected to eventually merge into a single program. The third prospect, aimed at satisfying urgent operational requirements, must be well aligned with in-country and collaborative efforts, and fully conform to operational requirements. Arguably, the only alternative that could live up to this tall order is an off-the-shelf acquisition of Europe's existing air and missile defense solution so as to meet urgent needs. Paradoxically, this may well be the only option decision-makers in Ankara have not yet diligently exercised.

\section{Bibliography}

Acar, Cemal. "S-400'de hangisi yanacak: kapora m1, F-35 mi, NATO mu?” odatv. Accessed May 9, 2018. https:// odatv.com/s-400de-hangisi-yanacak-kapora-mi-f-35-mi-nato-mu-07051815.html.

Acet, Mehmet. "Sırada ne var?” Yeni Şafak, October 30, 2017.

AK Parti Ar-Ge Başkanlığı. "S-400 Hava Savunma Sistemi Bilgi Notu.” t24. Accessed January 13, 2018. http://t24. com.tr/files/20180111140447_s-400-bilgi-notu.pdf.

Bekdil, Burak Ege. "Controversy Deepens over Chinese Air Defenses for Turkey.” Defense News, October 7, 2013.

. "French Industry Seeks a Comeback to Turkish Market." Defense News, March 10, 2014.

“Turkey May Adopt Chinese Air Defense System.” Defense News, June 24, 2013.

“"Turkey Mulls Stopgap Air Defense Acquisition.” Defense News, November 15, 2015.

Chulkovskaya, Yekaterina. "Is Russia's Planned Missile Sale to Turkey the Real Deal?" Al-Monitor, May 10, 2017. Accessed May 15, 2017. https://www.al-monitor.com/pulse/originals/2017/05/ russiaplanmissilesaleturkeymilitary.html.

Cooper, Tom. "Russia’s Air Defense in Syria Have Some Big Problems.” War Is Boring, October 6, 2017. Accessed July 24, 2018. https://warisboring.com/russias-air-defenses-in-syria-have-some-big-problems/.

Çamlıbel, Cansu. “Turkey Cannot Ignore Western Concerns over Missile Deal.” Hürriyet Daily News, February 17, 2014.

Çavuşoğlu, Mevlüt. "Dışişleri Bakanı sayın Mevlüt Çavuşoğlu’nun Zeit Online'da yayımlanan mülakatı.” By Michael Thumann, Zeit Online, March 9, 2018. Accessed March 12, 2018. http://www.mfa.gov.tr/disisleribakani-sayin-mevlut-cavusoglu_nun-zeit-online_da-yayimlanan-mulakati_-9-mart-2018.tr.mfa. 
Demirtaş, Serkan. "S-400s Becoming a More Difficult Issue for Turkey-NATO Ties.” Hürriyet Daily News, March $14,2018$.

Egeli, Sitk1. "Fighter Jet that could Break US-Turkey Defense Relations.” Middle East Institute, June 26, 2018. http://www.mei.edu/content/article/fighter-jet-could-break-us-turkey-defense-relations.

—. Füze tehdidi ve NATO füze kalkanı: Türkiye açısından bir değerlendirme. İstanbul: Bilgi Üniversitesi, 2014. "S-400 alımı, hava savunması, füze savunması, NATO: mitler ve gerçekler.” Kokpit.aero. Accessed August 2, 2017. http://www.kokpit.aero/s400-sitki-egeli.

__. "Turkey Embarks Upon Ballistic Missiles: Why and How?” Uluslararası İlişkiler 56 (2017): 3-22.

Ebbutt, Giles. "NATO ACCS Passes Major Milestone.” Jane’s International Defence Review, May 2013.

Elekdağ, Şükrü. "Rusya ile yapılan S-400 anlaşması akılcı değil!..” By Uğur Dündar, Sözcü, September 6, 2017. Accessed September 8, 2017. https://www.sozcu.com.tr/2017/yazarlar/ugur-dundar/rusya-ile-yapilan-s-400anlasmasi-akilci-degil-2000282/.

Gürcan, Metin. "US, NATO Wait to See if Russia-Turkey Defense Deal Goes Through.” Al-Monitor, August 1, 2017. Accessed August 2, 2017. https://www.al-monitor.com/pulse/originals/2017/07/turkey-russia-westmissile-defense-system-crisis.html.

Güvenç, Serhat, and S1tkı Egeli. “NATO’nun füzesavunma sistemi ve Türkiye.” Ortadoğu Analiz 40 (2012): 19-30.

Hickey, Samuel. “Turkey’s New Missiles.” Foreign Affairs, October 20, 2017. Accessed July 22, 2018, https://www. foreignaffairs.com/articles/turkey/2017-10-20/turkeys-new-missiles.

Kasapoğlu, Can. “Turkey’s S-400 Dilemma.” EDAM Foreign Policy and Security Paper 2017/5. Accessed August 1, 2017. http://edam.org.tr/en/turkeys-s-400-dilemma/.

Kasapoğlu, Can, and Sinan Ülgen. "Is Turkey Sleepwalking Out of the Alliance? An Assessment of the F-35 Deliveries and the S-400 Acquisition.” EDAM Foreign Policy \& Security 2018/6. Accessed August 15, 2018. http://edam.org.tr/en/is-turkey-sleepwalking-out-of-the-alliance-an-assessment-of-the-f-35-deliveriesand-the-s-400-acquisition/.

Kılıç, Hakan. “Çin füzesi almalı mıyız?” Kokpit.aero. Accessed April 2, 2015. http://kokpit.aero/hakan-kilic-cinfuzesi-almali-miyiz.

Kibaroğlu, Mustafa. “Analiz - NATO’nun S-400 itirazında çifte standart.” Haberler. Accessed July 29, 2017. https:// www.haberler.com/analiz-nato-nun-s-400-itirazinda-cifte-standart-9875394-haberi/.

Kibaroğlu, Mustafa, and Selim Sazak. "Why Turkey Chose, and Then Rejected, a Chinese Air-Defense Missile." Defenseone. Accessed June 18, 2017. https://www.defenseone.com/ideas/2016/02/turkey-china-air-defensemissile/125648/.

Korkmaz, Sertaç Canalp, and Arda Mevlütoğlu. “Turkey's Air Defense Umbrella and S-400.” ORSAM Center for Middle Eastern Strategic Studies Report No: 213, September 2017. Accessed September 27, 2017. http://orsam. org.tr/en/turkey-s-air-defense-umbrella-and-s-400/.

Kucera, Joshue. “Turkey Insists it is Solving Chinese T-Loramids Dilemma.” IHS Jane's Defence Weekly, November $14,2013$.

Magnuson, Stew. "Hypersonic Weapons Race Gathers Speed." National Defense Magazine, last modified October 10, 2015. http://www.nationaldefensemagazine.org/archive/2015/August/Pages/ HypersonicWeaponsRaceGathersSpeed.aspx.

Mehta, Aaron. "NATO Official: Turkey Faces Consequences if Purchase of S-400 Completed." Defense News, October 25, 2017.

Mitchell, Ellen. "Air Force Secretary Advocate Export Control Fixes amid Controversy over Turkey." The Hill, May 29, 2018.

Özgül, Levent. “Derin Kriz: S-400 mü, F-35 mi?” Kokpit.aero. Last updated August 4, 2018. http://www.kokpit. aero/s400-mu-f35-mi.

Sağlam, Erdal. "Merrill Lynch Refuses to Serve Turkish Defense Firm." Hürriyet Daily News, December 5, 2013.

Sariibrahimoğlu, Lale. “Turkey Abandons USD4 Billion T-Loramids SAM System Buy.” Jane's Defence Weekly, 
January 30, 2013.

"Turkey to Buy and Co-develop T-Loramids SAM.” Jane’s Defence Weekly, March 27, 2013.

Sazak, Selim C., and Çağlar Kurç. "Turkey’s Slow-Cooking Crisis With Its Allies Is Coming to a Boil.” Defense One, June 22, 2018. Accessed June 25, 2018. https://www.defenseone.com/ideas/2018/06/turkey-crisisallies/149203/.

Scmia, Emanuel. "Turkey’s Controversial S-400 Missile Transfer is Done Deal." Asia Times, June 30, 2018.

Seren, Merve. “Turkey’s Quest for a National Missile Defense System - Prospects and Challenges.” SETA Analysis, 2017. Accessed April 27, 2017. https://setav.org/en/assets/uploads/2017/04/Analysis_26.pdf.

Sokolski, Henry. "In the Middle East, Soon Everybody Will Want the Bomb." Foreign Policy, May 21, 2018. https:// foreignpolicy.com/2018/05/21/in-the-middle-east-soon-everyone-will-want-the-bomb/.

Stein, Aaron, and Can Kasapoğlu. "Turkey Goes Chinese for Missile Defense.” EDAM Discussion Paper Series 2013/12. Accessed October 21, 2013. http://edam.org.tr/wp-content/uploads/2013/10/Turkey-Goes-Chinesefor-Missile-Defense.pdf.

Sünnetçi, İbrahim. “CPMIEC ve EuroSam'ın gözünden T-LORAMIDs.” Savunma ve Havacıllk 166 (2014): 43. . "Eylül 2013 SSİK toplantısı kararları.” Savunma ve Havacılık 157 (2013): 102.

Tol, Gönül and Nilsu Gören. “Turkey’s Quest for Air Defense: Is the S-400 Deal a Pivot to Russia?” Middle East Institute Policy Focus 2017-5. Accessed December 12, 2017. http://www.mei.edu/content/turkey-s-quest-airdefense-s-400-deal-pivot-russia.

Yinanç, Barçın. “Turkey could Face US Sanctions for S-400 Purchase.” Hürriyet Daily News, February 1, 2018.

Withnall, Adam. "Erdogan Blames Foreign Powers for Coup and Says West is Supporting Terrorism." The Independent, August 2, 2016. 